MAURA STANTON was born in 1946 in Minneapolis. She received an M.F.A. from Iowa in 1971, and currently teaches writing at the University of Richmond. Her poems have appeared in Poetry, Poetry Northwest, The New Yorker and many other magazines.

\title{
THE FIRST CHILD
}

I grow dumb: the snow crops pine from the hill until only dark bark flaws the white everywhere. This is nowhere. The child knuckled in my belly is no one, a muscle, a blind fish nervous at its hook. Each day it devours my speech until I dream, surely I am a fish beached somewhere on an iceberg. This isn't love. My husband keeps his hands away, quoting statistics: the trauma of young wives in their first pregnancy. He thinks I match some percent, that I won't jab our baby with long hatpins or feed it ammonia. Doesn't he see how it puffs within me, trying to get out? How it nibbles my brain? I want him to understand how frost comes: to see white fear wall me in like a glacier\& see this child at my eyes cracking its way to air.

\section{CRABS}

The new in-laws steam crabs for my wedding, the aunts mumbling how many kids can cram at her breasts? Trapped in the crab-pot, red claws clamp on each other's eyes for safety. 
All night I hear that dance, the flesh blistering white under the blue shell-bone. Surely I ate their poison, that forbidden membrane caging the sweet meat. Sleeping, my husband belongs to these ladies who root in my belly, tongs flashing, tongues bitter with the need for children. They admire my skin. I see it peel off: My lip will fall that way; the nose-bone grub forward. My great-grandmother's casket photograph showed a woman's chin caved-in like tub lard. Tonight the mirror is precise. I imagine everything, me, hare-lipped, earless, a thousand maggots at the brain.

\section{IN IGNORANT CADENCE}

The chemical tapestry of your brain amazes the heart of you, all those ions \& neural protons

clicking into scenes or wishes. Your tongue is alive in your mouth like a slippery fish

so why can't you say anything? Even Philomela, throat staunched with rags, managed to shred her weaving fingers

until the thread equaled recklessness from once upon a time. The tongue of a bird is a delicacyyours, a distraction you never understood, a hopeless slab of muscle forever wobbling on the edge of song. 